\title{
HTR2C Gene
}

National Cancer Institute

\section{Source}

National Cancer Institute. HTR2C Gene. NCI Thesaurus. Code C115016.

This gene is involved in neurotransmitter-dependent G protein-coupled receptor signaling. 